\title{
Research of Counselor Professional Ability Development under the View of New Media
}

\author{
Jingjing $\mathrm{GaO}^{1}$ \\ ${ }^{1}$ Xi'an Fanyi University, Xi'an, Shaanxi, 710105 \\ Topics: Shaanxi Province, the task of teaching \\ 59624917@163.com
}

Keywords: New Media; Counselor; Professional Ability

\begin{abstract}
With the development of science and technology and economic growth, education is faced with a lot of changes. The emergence of new media pointed out a new direction of development for ideological and political management in the universities, but also increased the difficulty of the work, making the student counselor for political management more complex. This requires colleges and universities to strengthen the students' ideological and political instructor management, and constantly improve their professional competence to contribute their strength for the university management. In this paper, the impact of new media on the work of college counselor is analyzed and puts forward methods to build capacity of counselor under the new media.
\end{abstract}

\section{Introduction}

New media blitz by college students, students 'thinking and behavior by the impact of new media, which bring new development opportunities to the college students' ideological and political education work, but also poses a severe challenge to the ideological and political management. College Counselors are perpetrators students' ideological education work, so the ideological and political education instructor is able to smoothly expand and professional competence are closely related. Therefore, to enhance the professional capacity counselor for ideological and political education is a huge help.

\section{The Effect of New Media on the Work of Counselor}

Mode Change. The traditional mode of ideological and political education instructor in charge of preaching is, strictly require students to obey the arrangement, but under the influence of new media has not suited to the development of this mode of education of students, depending on the requirements under the new media valve counselor during the ideological and political education work should be student-oriented, adhere to the student-centered, in the ideological and political education work with students to talk of equality [1]. This requires that counselors have a more rich professional knowledge structure, assist the implementation of the ideological and political education.

Decrease Counselor's Personal Charm. Depending on the valve so that the new media authority under reduced counselor, authority mainly refers to the instructor's personal charm and glamor of knowledge, etc., because the traditional sources of information to educate students mainly rely on counselors, which increases the student counselor hearts lofty self-image, so that counselors become a model student that counselor magical wand. But the widespread use of new media allows students to continue to broaden access to information, when students learn to select information, students' self-charisma have enlightened exercise and promotion, so that students are no longer solely rely on counselors to obtain information. Making authority has been weakened counselor.

Expand the Path and Form. The Internet is the most representative of the development of new media, the Internet in the form of performance for a variety, the level is not poor, strong impact of the human visual and auditory senses as well, so that students' horizons constantly being enriched. Students have to make management changes, the traditional management model is not suitable for 
the development of the present era, but also to the management of new media provide more management journey, rich forms of management, strengthen the interaction between instructors and students.

\section{The Work about Hold Stability Function}

The new information and communication media have quick and convenient features, which makes the dissemination of information regardless of time constraints between these information corresponding impact on their mental and thinking are some sensitive issues so that students prone to excesses [2] . For example, in "Diaoyu Islands", the country has shown a university student stormed Japanese products shop, destruction of goods, burning Japanese cars and some other excesses.

\section{The Method to Enhance the Professional Competence of Counselor}

Some scholars said, the information society, the biggest lie in the gap between two generations, when children occupied the world's information resources, you need to study hard to catch up adults [3]. In the new media environment, the counselor should take advantage of new media technologies and scientific management for college students, which is imminent for each College Counselors work.

Strengthening New Media Art. Depending on the requirements of the new media counselor valve under study should be appropriate to the new media technology, be good at discovering new media features, combined with the characteristics of education, making the new highly integrated media and education. This requires, first counselor with the new media consciousness, and does not ignore the impact of new media on the contemporary college students, always with a sense of urgency and responsibility, understand the changes in the new media, as the valve ideological activity and mental activity of students, as well as new media for college students' behavior impact activities, combined with new media features as possible in the management strengthen the management of college students, which can effectively enhance the ability to foresee college counselors.

Improve Media Literacy. Media-like include instructor knowledge and understanding of the media to grasp the corresponding media capability, including the instructor's understanding of the media and did not remember application capabilities and the ability to create media [4]. This requires the counselor to be proactive education of new media communication of knowledge, skills and strategies to understand the method of information dissemination in learning, which allows instructors to enhance their media literacy in continuous learning, while schools can organize new media training counselors, counselor makes so tough to accept a new media literacy education, as well as expand the training school makes learning more purposeful, because the school counselor to start training is based on the actual work needs, in training You can take a variety of forms to start various training, such as through quizzes and knowledge competitions and other means.

The Right to Vote. Counselors have right to speak requires counselors to change the attitude of contempt network discourse actively into new media, as the valve, learn to use Internet language in their daily management work, so you can narrow the relationship between students so that students feel between counselor and no barriers. It also should enhance the right to speak, preaching step reduction in education, increasing the number of student exchanges. So that students feel relaxed and equality in exchange, no longer strictly educational purposes by way of talking education, allows students to establish and improve the healthy life of faith. The right to speak counselors need ongoing study of political theory, and constantly improve their professional knowledge, enhance their information application skills, make their own personal charm continues to increase. This will let the students full of admiration and respect for counselors so that counselors work more Effectiveness [5].

The right to speak but also requires the counselor to accurately grasp the psychological change characteristics and ideological characteristics of contemporary college students, good at discovering the interests of students, in the management should be able to make mutual rapport between the two parties, in exchange with students Do not give students a condescending feeling, should be 
combined with the characteristics of the new media in the exchange between students, making students feel genuinely care from counselors. Teachers and build harmonious coexistence of the situation, in the exchange fully reflect the humanistic spirit and humane care characteristics. Meanwhile counselor should be ranked in the management of high ground, which requires the counselor should enhance self-motivated professional competence, timely grasp of social public opinion. Thus in some unexpected events can effectively control, it requires attention counselor electronic bulletin board systems as well as in various forums and micro-blogging changes, as well as strengthening the information filtering process, when detecting adverse information to students, should be promptly shield and guide students to correct things carry on non-discrimination.

Establishment of a Working Module. Depending on the valve under the new media, college students should also be thinking of new media innovation, makes the new media more benefit student learning and life. Counselor education through the establishment of a new media platform can be used to strengthen management of the students. The new media can give education more rich educational resources, use of new media technologies in education so education is also capable of advancing, while the ideological and political education under the new media, as the valve can be a combination of organic and traditional ideological education, so today Educational more scientific, in line with the development needs of the students. New media education module requires counselors to strengthen the focus on Internet content to influence college students brought to the educational work quickly to make changes, so that makes education more close to reality, so that students in the Internet can adhere to the Party's guidelines, to strengthen the inculcate the idea of socialist core values.

The establishment of new media exchange module. This requires that counselors should establish a personal professional work site, the students' learning and communication methods as well as employment prospects and career planning information dissemination in the work site, and can also publish your phone number and mailbox in the site and other micro letter Information, so you can easily keep in touch with their students, but some students are more restrained, something embarrassed and counselors to communicate face to face, this time students can communicate at work site anonymously with a counselor.

Create a new media self-education module. Create a new media self-education requires not only college counselors should actively educate themselves, but also college students should be required to carry out self-education, you can choose a number of outstanding moral character and strong IT student groups learn to say too as a network information manager, under the guidance students assist students in self-education, and self-management and self-development in the new media, as the valve, allow students to drive students to educate themselves, thus reducing the gap because it allows students reluctant to self-education, pull near the relationship between students, while students a better understanding of the student population, provides a convenient and effective way for students' ideological and political education.

Constantly Improve Their Own Capacity. And improve their capacity can be achieved by continuing education instructor in the post, while at the hiring counselors should be strictly carried out. Pay attention to ideological and political quality and level of expertise of the counselors, as well as new media can not neglect counselor awareness and information processing capabilities, requiring new media counselors have a strong sense of the times during which appointments ongoing self-education capacity so we are constantly building their own excellence, continuous self-reflection self-improvement.

The Implementation of Reward and Punishment. "There must be rewarded under Isao" means under the generous reward stimulus, there will be a brave man to accept the task (the challenge) [6]. This sentence shows that also can be used in education, if the reward system in the implementation of the ideological and political management counselor can make work more orderly manner. While some schools are to implement reward system, but in the new media, as the valve should be created under incentive information capabilities, develop appropriate evaluation system, but to develop the evaluation system should actually work with a counselor at the appropriate phase. In the form of rewards and punishments it may also be a spiritual substance, which can effectively motivate 
counselors continue to improve, stimulate the enthusiasm of the counselors, but also the ability to activate potential career counselor. And this was conducive to competition among counselors, so that professional competence counselors rising, making the construction of university even more brilliant.

\section{Conclusion}

The popularity of the new media make undergone enormous changes for people's life, but also brings new opportunities and challenges to the work of college counselors, college counselors should be downwind to seize the opportunity to accept the challenge. They should discover new media era of information dissemination characteristics, conduct a good job of ideological and political education of college students and adhere to the education of students taught to lead the growth of service principle.

\section{References}

[1] Fan Wei, Sun Ning. From The Media Perspective of College Counselors Network Media Literacy Promotion of. Chinese Newspaper, 2014,02: 21-22.

[2] Chen Yong, Lu Na, Li Sheng, Chen Ting. College Counselors Enhance Professional Competence in the New Media Environment. Chongqing University of Technology (Social Sciences), 2014,02: 137-139.

[3]. Yue Tian, Fan Gaoshe, Yang Hua. College Counselor Professional Ability in The New Media Environment to Enhance the Routing. Journal College Counselors, 2015,02: 24-27.

[4] Yuan Jingjin. College Counselors From Upgrading Professional Competence Under The Background Of Media To Explore. Road to Success, 2014,34: 3.

[5] Zhang Daibao. New Generation of Education Under New Media Environment College Counselors Work. Science And Technology Information, 2012,20: 48 + 51 .

[6] Guo Xiaofeng, Song Yanmin. New Exploration Collaborative Management Perspective Counselors Colleges. Social Sciences Review, 2013,01: 154-157. 